Eurasian Journal of Business and Economics, 14(27), 1-28, (2021).

\title{
Determinants of the Financial Constraint and Its Effects on the SME Growth in Central Asia
}

\author{
Mirgul NIZAEVA*, Ali COSKUN ${ }^{* *}$
}

Received: April 11, 2021

Revised: May 27, 2021

Accepted: May 30, 2021

\begin{abstract}
This study investigates the firm-and country-specific factors that affect SMEs' access to finance and the relationship between financial constraint and firm growth in emerging economies of Central Asia. To address the research questions, a two-stage empirical analysis including ordered probit, probit, and feasible generalized least squares (FGLS) specifications were conducted. Firm-level data used in the analysis is obtained from the fifth round of the Business Environment and Enterprise Survey (BEEPS V) and country-level data acquired from national and international datasets. The study's findings implied that in the Central Asian economies, country-specific factors are more likely to affect access to external finance of SMEs than firm-specific determinants. Among firm-specific factors, only foreign ownership is significantly related to financing constraint perception of SMEs; where, the interest rate is positively, and domestic credit market, inflation, and log of GDP per capita are negatively related to financing constraint level. In Central Asia, an insignificant relationship between growth and financing constraints was found. The determinants of financing constraints and access to finance-growth relations, which address the issue of great significance for SME growth in the selected countries, were interpreted with region-specific factors.
\end{abstract}

Keywords: Access to finance, BEEPS V, Central Asia, Growth, Small and medium-sized enterprises.

JEL Code Classifications: G320, G30, C21.

UDC: 334.012.64, 334.012.8

DOI: https://doi.org/10.17015/ejbe.2021.027.01.

\footnotetext{
*PhD, Regional Institute of Central Asia, Bishkek, Kyrgyzstan. Email: mirgulnizaeva@gmail.com

** Professor, American University of the Middle East, Egaila, Kuwait. Email: ali.coskun@aum.edu.kw
} 


\section{Introduction}

The role of small- and medium-sized enterprises (SMEs) in the development of former command emerging economies demands peculiar attention. The creation of SMEs in formerly planned economies can be considered an important part of economic transition (Carree et al., 2002). The entry of new firms in the early stages of transition had a crucial role in the economic progress of previously planned economies. Economic restructuring and mass privatization in most of the postcommunist countries resulted in labor shedding, and the newborn smaller firms assisted economies in retaining the employment level in that stage (Hashi \& Krasniqi, 2011). In most developing countries, small firms create the largest share of jobs and have the highest sales growth (Ayyagari et al., 2014). However, business environment-related obstacles prevent the growth of SMEs and diminish their contribution to overall economic growth. Facilitating access to finance and land, reforms in taxation and administration, licensing, permits, and customs would advance the performance of private firms (Gogokhia \& Berulava, 2020).

Among other business environment-related obstacles, the financing constraint has been found as a more severely growth restrictive factor for SMEs. Compared to large firms, SMEs are more financially constrained, relying mostly on internal and informal financial sources, since their loan applications are more likely to be refused (Hashi \& Toçi, 2010; Wang, 2016). In economies where informational infrastructure is weakly developed, informal economic activities are prevalent; it is not possible to evaluate the financial statements of SMEs. Small business entities are required to provide pledge collateral for borrowing. Since SMEs have relatively low probabilities of holding assets that may be pledged as collateral, they are more likely to perceive access to external financing as severe business obstacles (Yaldız Hanedar et al., 2014). Access to external finance positively affects the growth of SMEs, where bank loans have the strongest effect, followed by other non-bank formal external sources (Girma \&Vencappa, 2015).

Although there has been a common view that financing constraints impede firm growth, there also some recent findings that argue the non-existence of a significant relationship between access to external finance and firm growth in developing economies and rural areas. Beck et al. (2015) found that even though loan from formal financial institutions has been perceived as a more effective tool in mitigating financial constraints, due to limited scale and comparatively higher interest rate of informal finance, the formal finance use is not associated with higher firm growth in terms of sales. The significant positive association between bank credit and enterprise growth did not hold for their sample of firms. Léon (2020) indicated that small firms do not benefit from long-term bank loans, but short-term credits are beneficial for their growth. According to Allen et al. (2012), due to the reliance of small firms on informal finance, they are not impeded by a lack of borrowing from financial institutions, particularly bank loans. In fact, small enterprises, which use informal and internal sources, do not do worse than those larger firms with easier 
access to bank credits. In emerging markets, the capabilities of SMEs are embedded in the industry, institutional, and firm-specific conditions (Sun et al., 2021). Thus, in developing countries with weak institutional environments, informal funding beyond the legal system and formal administration may minimize the costs related to the inefficiency of legal institutions, and it is easy to adapt better.

The key objectives pursued by this study to contribute to the discussions around SME financing - growth association, are as follows. First, in the literature, the determinants of SMEs' financial constraints and finance-growth relations have been examined separately. There is a lack of research that has undertaken the comprehensive analysis of financial constraint determinants and the effect of difficulties in access to finance on SME growth. This study attempted to fill this gap, come with extensive findings, and provide strong interpretations. Second, since access to the financial market of SMEs is not only a vital condition for their growth and survival, it is more critical for economic growth and catching-up effect of emerging economies with developed economies. Therefore, this study sheds light on the determinants and impact of financing constraints on the growth of SMEs for a sample of developing country groups that have been paid less attention. Third, previous studies investigated the access to finance and the growth of SMEs in the case of a large number of developing countries, and there is no research in the case of Central Asian economies. Considering the importance of economic, political, and other factors on SME financing, in this study, the Central Asian regions were investigated, and implications were provided.

The remaining of the paper is organized as follows. Section two reviews the relevant literature. Section three explains the methodology and data, where sections four and five discuss the findings and conclusion, respectively.

\section{Literature Review}

In the relevant literature, it has been indicated that compared to large firms, SMEs are more financially constrained since their loan applications are more likely to be refused due to inadequate credit history of small firms, high-risk premiums, high transaction costs (Mateev et al., 2013), interest rates charged are high (Hashi \& Toçi, 2010; Wang, 2016), bank collateral requirements are not affordable (Beck et al., 2016). Moreover, inefficient financial system functioning, weak contract enforcement, corruption, macroeconomic fluctuations, business regulation, and governance relevant obstacles adversely affect SMEs' access to finance; where, only constraints related to finance, crime, and political instability have a significant direct impact on firm growth, and other reported obstacles have indirect effects (Ayyagari et al., 2008).

Even though a negative relationship between financial constraints and SME growth has been evidenced, findings are mixed. One stream of the literature argues that among other obstacles, financial constraint is considered as the robust growth impeding factor for SMEs (Ayyagari et al., 2016; Fowowe, 2017; Ullah, 2020). The 
small firms that have limited access to external financial sources are severely constrained in realizing their potential growth prospects and not able to reach their optimal size since their applications for external financing, especially long-term loans, either for investing or working capital needs, are rejected (Musta, 2017a). Access to external finance positively impacts firm growth (Khaleque, 2018), with bank loans having the strongest effect followed by other non-bank formal external sources and government funds, where small firms benefit from having better access to bank loans more than larger firms (Girma \& Vencappa, 2015). In previously command economies, where a financial market is not developed growth of small firms is severely impeded by a lack of access to finance (Ullah, 2020). Employment growth difference among SMEs with and without access to external finance is at least three times larger than the employment growth difference among large firms with and without access to finance (Ayyagari et al., 2016).

Another stream evidences the non-existence of (Saeed, 2009; Mohamad et al., 2015; Allen et al., 2012; Beck et al., 2015) and the negative relationship between access to external finance and SME growth in the developing economies (Regasa et al., 2019). Such differences in access to finance-growth relations have been interpreted with varieties in financial system functioning, regulation, and other macroeconomic indicators across economies. Allen et al. (2012) argue that SMEs, which use informal and internal sources, do not do worse than those larger firms with easier access to bank credits, since in developing countries with weak institutional environments, informal funding beyond the legal system and formal administration may minimize the costs related to the inefficiency of legal institutions, and it is easy to adapt better.

\subsection{Financial Constraint and Its Determinants}

Previous studies which examined the financing patterns and determinants of SMEs' access to external finance have found that firm size, accounting information transparency, age (Barth et al., 2011; Gregory et al., 2005), ownership type (Barth et al., 2011; Beck et al., 2006; Hashi \& Toçi, 2010) are mostly considered as firm-specific attributes that affect the financing constraint. The loan applications of older, larger firms are less likely to be discouraged, where size is the robust predictor associated with the discouragement probability (Chakravarty \& Xiang, 2009).

According to Mateev, Poutziouris, and Ivanov (2013), in transition economies, the financing decision differences among small firms in different industries are affected by firm characteristics rather than to industrial differences; where, financial constraint seems to have a more severe impact on the performance of manufacturing firms than on the performance of enterprises operating in the service sector (Kresic et al., 2017). Firms operating in the trade sector have a shorter cash conversion cycle than enterprises in other sectors, which enables them to generate cash for their operational needs in a comparatively shorter period. It makes manufacturing firms tend to find that obstacles related to access to finance have a more severe impact on their performance than firms in services (Krešić et al., 2017). 
In the literature related to SME financing, ownership is another important factor used to explain financing constraint levels of small firms. Foreign ownership is negatively correlated with the level of financing constraints (Wang, 2016). Foreignowned enterprises, especially those operating in developing economies and originated from advanced economies, are expected to perceive access to finance lower constraints than their domestic counterparts. This may be interpreted with the fact that they are able to obtain funds through access to the financial market in their home country (Krešić et al., 2017). Foreign-originated SMEs operating in developing economies report less financial constraint than their domestic counterparts due to their ability to obtain relatively cheaper, long-term finance or to fund their investments via their parent companies in the advanced economies, makes them financially less constrained (Nizaeva \& Coskun, 2018).

Another robust determinant of financing constraints is age; as the operating year increases, the enterprise gets financially less constrained (Beck et al., 2006). On the one hand, supporting the negative association between firm age and financial constraint level, Kira (2013) stated that younger firms face serious financial problems due to information asymmetry between the lending institution and the informational opaqueness of newly established firms. On the other hand, another stream of literature found no relationship between firm age and financing constraint level (Musta, 2017b) and also found a negative association between firm age and access to finance (Hashi \& Toci, 2010; Nizaeva \& Coskun, 2019), indicating that as firm ages, it becomes financially more constrained.

Based on their scope of operation, small firms demand relatively smaller loans, and typically they are informationally opaque and hold fewer assets that may be pledged as collateral. Dias Duarte et al. (2017) found that in developing economies of Central Asia and Eastern Europe, the high collateral requirement is one of the most important reasons that make small firms not apply for credits, and in most of the cases, the creditworthiness is measured with the personal wealth of entrepreneurs, since generally small firms lack tangible asset to pledge. As the bigger and older the SMEs, they are likely to perceive access to financing as a less severe obstacle (Wang, 2016).

In addition to firm-specific factors, variations in access to finance of firms are determined by country-specific factors rather than firm-level factors (Mateev et al., 2013). Since the economic performance of the countries is the outcome of the functioning of financial, legal, administrative, and regulatory systems, SMEs in more developed countries may face fewer obstacles. Enhancements in formal financial sectors alleviate financing obstacles more for small firms that have difficulty in either self-financing or finding private funding (Beck et al., 2009). In economies where the debt market is underdeveloped, and equity financing is not accessible, SMEs use more short-term debt (Kumar \& Rao, 2015). Beck et al. (2008) implied that institutional development, better functioning regulative environment, particularly property right protection, are the most affecting factor of small firms' financing 
patterns. They also found that an effectively functioning financial intermediary system, particularly the banking sector, impacts on external financing of smaller firms more than their larger counterparts. The literature suggests that institutional quality improves the bank intermediation (Antoun et al., 2021); regulatory environment and the banking development are important determinants of firms' financing behavior and financing constraint perception (Ayyagari et al., 2016).

It was also found that all business environment-related obstacles are lower in larger and fast-growing economies, but financing obstacles are significantly higher in economies with high inflation rates (Beck et al., 2005). The average inflation rate over the sample period provides both an indication of the Government's management of its economy and evidence on whether the local currency provides a stable measure of value to be used in long-term contracting. During inflationary periods, banks increase their lending rates to cover their costs. Wang (2016) indicated that in developing economies, for small firms in need of external funds, the most severe constraints are the high cost of borrowing, complex loan application procedures, and collateral requirements. Commercial banks operating in economies with high non-performing loan-to-GDP ratios tend to charge higher interest rates and use more cautious lending, especially to small firms (Barth et al., 2011). Moreover, as it was experienced in most developing economies, the entry of big foreign banks into emerging economies may undermine the development of the domestic banking sector and considerably increase bank concentration (Dong \& Men, 2014). Banks in the concentrated banking sector use their market power to apply collateral-based lending to screening efforts rather than mitigating observable risk (Dias Duarte et al., 2017) and lend less to SMEs. Domestic credit provided as a percentage of GDP is negatively associated with financial constraint perception of SMEs, and bank loan was reported the most important source of firms' external financing (Dong \& Men, 2014). In Central Asia, SMEs have lower shares in overall bank lending than in other regions (Ghassibe et al., 2019).

\subsection{Other Variables Affecting SME Growth}

In the literature related to SME growth, in addition to financing obstacles, the crucial roles of characteristics of firms and the external business environment are recognized. Along with analysis of the relationship between financial constraint and growth of SMEs, other firm-specific (manufacturing, trade, foreign ownership, size, and age) and country-specific (GDP as a proxy for economic development and private sector regulation indicator) variables are tested. SMEs operating in different industries and with foreign or domestic ownership are unlikely to have different growth rates (Hashi \& Krasniqi, 2011). In the contexts of post-communist developing economies, due to their instability, inconsistency, and high costs of compliance, the regulative environment has mainly acted as obstacles to business growth (Xheneti \& Bartlett, 2012). In Central Asian economies, enduring practices of informal business relationships perpetuated by the legacy of the established economic systems (Makhmadshoev et al., 2015) adversely affect the growth of small firms. 


\section{Methodology}

An empirical methodology applied in this study is derived from the literature that focused on financing constraints and SME growth issues. For the purpose of empirical estimations and robustness of the findings, various econometric models probit, ordered probit, Feasible Generalized Least Squares (FGLS), as well as Ordinary Least Squares (OLS) regressions, are employed to test the parameters.

\subsection{Sample and data}

Enterprise-level data used in the analysis is obtained from the fifth round of the Business Environment and Enterprise Survey (BEEPS V) that is the joint project of the European Bank for Reconstruction and Development (EBRD) and World Bank Group (WBG). BEEPS $V$ was undertaken in 2012-2016 and covered 16,600 firms in 32 countries which were updated as of August 2017. The database provides the following advantages. First, it uses a standard questionnaire across all countries, which makes it possible to compare firm-level data between countries. Second, it covers the data on firm attributes, their performance, and perception of business environment features, including physical and financial infrastructure, legal, administrative, political, and regulative systems in different economies, which enable us to assess the impact of financial constraint on SME growth in similar country groups and compare and contrast between countries.

The macroeconomic data, including inflation, GDP per capita, interest rates of individual countries, are acquired from the World Development Indicators (WDI) dataset of the World Bank and private-sector regulatory from the World Governance Indicators (WGI) (Kaufmann et al., 2016). Moreover, the data of domestic credits provided to the private sector as a percentage of GDP is acquired from the Financial Access Survey (FAS) of the International Monetary Fund (IMF). The data on banking sector concentration is obtained from Financial Development and Structure Dataset by Demirgüç-Kunt et al. (2016). The lending interest data for Uzbekistan and Kazakhstan are obtained from The Central Bank of the Republic of Uzbekistan and the CEIC database, respectively. BEEPS V is cross-section survey data that had been collected during 2012-2016 in 32 developing economies, firms in countries in our sample are surveyed in 2013, and country-specific data for the analysis is also obtained for this corresponding year.

The distribution of the firms in the sample across countries is as follows: 489 firms in Kazakhstan, 239 firms in Kyrgyzstan, 254 firms in Tajikistan, 285 firms in Uzbekistan. Even though geographically, the region of Central Asia consists of five countries, due to the unavailability of both firm-level and country-specific data, Turkmenistan was not included in this study.

\subsection{Variable definition and descriptive statistics}

There are different measurement methods of financial constraint in empirical analysis. The two approaches that use the investment sensitivity to internal funds 
are Tobin's q and Euler equation of investment model. Another approach to the study of firm financing proposed by Demirguc-Kunt and Maksimovic (1998) estimated a financing model to obtain the maximum possible rates of growth that firms can reach without any access to external finance. By comparing these firms' growth rates without external financing with actual growth rates of firms, the authors inferred the degree to which firms are financially constrained. Unlike previous methods that derived financial constraints from financial statements of firms, another approach introduced by Beck et al. (2006) identified it directly based on the responses of firms about financial constraints. Given the listed companies' financial data reliance on previous empirical analysis, Beck et al.'s (2006) approach made it possible to extend investigations on financial constraints of small firms in emerging countries. In the selected economies, stock markets are less developed, and the economies are also dominated by small firms that are informally opaque and not listed. These conditions make it impossible to obtain the balance sheet and income statement data of small firms. Thus, using the survey data is more appropriate for investigating the financial constraints faced by SMEs in developing economies where the evidence on financial obstacles of small firms is scarce.

As has been used by Barth et al. (2011), Beck et al. (2006), Hashi and Toçi (2010), in the analysis financial constraint was measured based on the responses of firms to the survey question "Is access to finance, which includes its availability and cost, interest rates, fees, and collateral requirements an obstacle to the operation of this establishment," which ranged from 0 (no obstacle) to 4 (very severe obstacle). Following Wang (2016) and Hashi and Krasniqi (2011) for the purpose of the analysis, the values of levels of financial constraint were converted into dummy variables; "major obstacle" and "very severe obstacle" was scored as 1; otherwise, the score was 0 .

Firm growth was measured in terms of employment growth. In keeping with previous studies (Rahaman, 2011; Dinh et al., 2012; Leitner, 2016; Fowowe, 2017), employment growth is defined as the difference between the logarithm of current permanent employee number and permanent employee number three years ago divided by difference between survey years -3 .

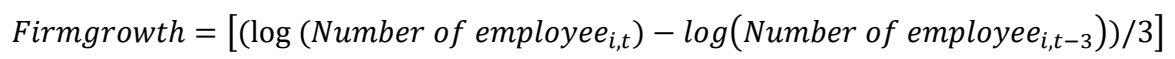

FirmSize is a number of permanent employees in a particular firm. Age is the number of years during which an enterprise has been operating in the selected country. Firm age was measured by subtracting the firm's year of establishment from the year when the survey was administered. Agesq is the square of the Age variable. Industry dummies for manufacturing and trade sectors were denoted as 1 if a firm operates in the manufacturing or trade sectors (wholesale and retailing) and otherwise 0 . The service sector was used as a base dummy. Foreign ownership is the percentage of a firm's shares that belong to foreign owners. 
The logarithm of GDP per capita in current US dollars (Loggdp) is used as a proxy for an economic development indicator for the selected countries. Inflation (measured by the consumer price index) is the annual change in the cost of acquiring a basket of consumer goods and services. Bank concentration (Bankconc) is the percentage of the three largest banks' assets to all the commercial banks in an economy. The regulation indicates the enforcement and quality of government regulatory policies on private sector development. The measurement unit for regulation, based on a standard normal distribution, with a mean value of 0 and a standard deviation of 1 , ranged between -2.5 (weak regulatory governance policies) and +2.5 (strong regulatory governance). Domestic credit refers to financial resources provided to the private sector by banks. It is measured as a total domestic credit provided to the private sector as a percentage of GDP. The interest rate is the rate charged for loans that usually meet the short- and medium-term financing needs of the private sector.

Table 1 and Table 2 present the descriptive statistics for the variables used in the analysis and statistics for macroeconomic variables, respectively.

\section{Table 1. Descriptive Statistics}

\begin{tabular}{lccccc}
\hline Variable Obs & Observation & Mean & Std. Dev. & Min & Max \\
\hline Firm growth & 1,266 & 0.010 & 0.051 & -0.291 & 0.434 \\
\hline Financial constraint & 1,266 & 0.130 & 0.337 & 0 & 1 \\
\hline Manufacturing & 1,266 & 0.316 & 0.465 & 0 & 1 \\
\hline Trade & 1,266 & 0.533 & 0.499 & 0 & 1 \\
\hline Foreign ownership & 1,261 & 5.094 & 19.196 & 0 & 100 \\
\hline Age & 1,263 & 13.067 & 9.038 & 1 & 86 \\
\hline Agesq & 1,263 & 252.346 & 551.204 & 1 & 7396 \\
\hline Firm size & 1,266 & 35.138 & 43.827 & 2 & 250 \\
\hline Loggdp & 1,266 & 3.529 & 0.495 & 3.021 & 4.143 \\
\hline Inflation & 1,266 & 7.131 & 2.508 & 5.010 & 11.7 \\
\hline Bankconc & 1,266 & 71.333 & 25.741 & 42.056 & 100 \\
\hline Regulation & 1,266 & -0.777 & 0.526 & -1.616 & -0.315 \\
\hline Interest rate & 1,266 & 17.448 & 4.577 & 12.880 & 24.330 \\
\hline Domestic credit & 1,266 & 24.636 & 9.442 & 15.180 & 36.190 \\
\hline
\end{tabular}

Table 2. Country-specific indicators across countries

\begin{tabular}{lcccccc}
\hline & $\begin{array}{c}\text { GDP per } \\
\text { capita } \\
\text { (current USD) }\end{array}$ & $\begin{array}{c}\text { Inflation } \\
(\%)\end{array}$ & $\begin{array}{c}\text { Concentration } \\
(\%)\end{array}$ & $\begin{array}{c}\text { Regulation } \\
\text { Credit (\%) }\end{array}$ & $\begin{array}{c}\text { Interest } \\
\text { rate (\%) }\end{array}$ \\
\hline Kazakhstan & $13,890.86$ & 5.84 & 42.06 & -0.37 & 36.19 & 12.88 \\
\hline Kyrgyzstan & $1,282.44$ & 6.61 & 68.57 & -0.31 & 21.32 & 15.19 \\
\hline Tajikistan & $1,048.67$ & 5.01 & 100.00 & -1.05 & 24.33 & 15.18 \\
\hline Uzbekistan & $1,907.55$ & 11.70 & 98.43 & -1.62 & 15.9 & 21.15 \\
\hline
\end{tabular}


As displayed, the variables are denoted by nominal and dummy values. The sample consists of entirely domestic, foreign, and partially-foreign owned SMEs. The age of the firms ranges between 1 and 86 years. The average inflation rate is $7.14 \%$ that ranges between $5.01 \%$ and $11.7 \%$. Moreover, bank concentration is significantly high in Central Asia, reaching $100 \%$, the mean value of the concentration is $71.33 \%$. The average value of the lending interest rate of loans to the private sector is $17.45 \%$, and the mean value of bank credit provided to the private sector as a percentage of GDP is $24.64 \%$.

The per capita GDP varies from USD1,048.67 (Tajikistan) to USD1,3890.86 (Kazakhstan). The assets of the three largest banks as a share of the assets of all the commercial banks in a country reach $100 \%$ in Tajikistan. The regulation measurement unit is below zero in all of the Central Asian economies have, where the measurement unit ranges between -2.5 (weak regulatory governance policies) and +2.5 (strong regulatory governance). Among selected countries, commercial banks in Uzbekistan charge the highest lending rate. The highest credit as a percentage of GDP is provided in Kazakhstan, and the lowest percentage is observed in Uzbekistan. The highest and the lowest interest rates are $21.15 \%$ and $12.88 \%$ in Uzbekistan and Kazakhstan, respectively.

Table 3 reports the correlation coefficients for the variables under consideration. A negative correlation is observed between firm growth and the financial constraint level. SMEs operating in the manufacturing industry seem to perceive access to external financing as a greater obstacle in comparison to their counterparts in the service and trade sectors in the sample. Older SMEs seem to perceive access to external financing as a serious obstacle, and foreign-owned enterprises are likely to be less financially constrained. Moreover, large firms tend to be older, and firm size and growth rate are positively correlated. SMEs operating in the manufacturing sector are likely to be larger, and firms in trade are likely to be smaller in terms of employment. There is a positive correlation between foreign ownership and firm size. A negative correlation has resulted between firm age and growth, which means younger enterprises grow faster than their mature counterparts.

A negative linear association between Loggpd, inflation, and financial constraints is observed in both regions. SMEs operating in more concentrated banking industries report higher financial constraints. The positive correlation between regulation indicator and financial constraint is reported, which means firms in economies with higher regulation indicators perceive access to finance as an obstacle. Interest rate and financial constraint are positively correlated means that as high as the interest rates, SMEs are more financially constrained. A negative correlation between domestic credit and level of financial constraint is reported. In economies with larger credit markets, SMEs are less financially constrained.

Bank concentration and inflation variables are negatively correlated with domestic credit; in economies where inflation and bank concentration are low, domestic credit 
to the private sector as a percentage of GDP is high. The interest rate is negatively correlated with inflation and Loggdp.

Table 3. Correlation Coefficients

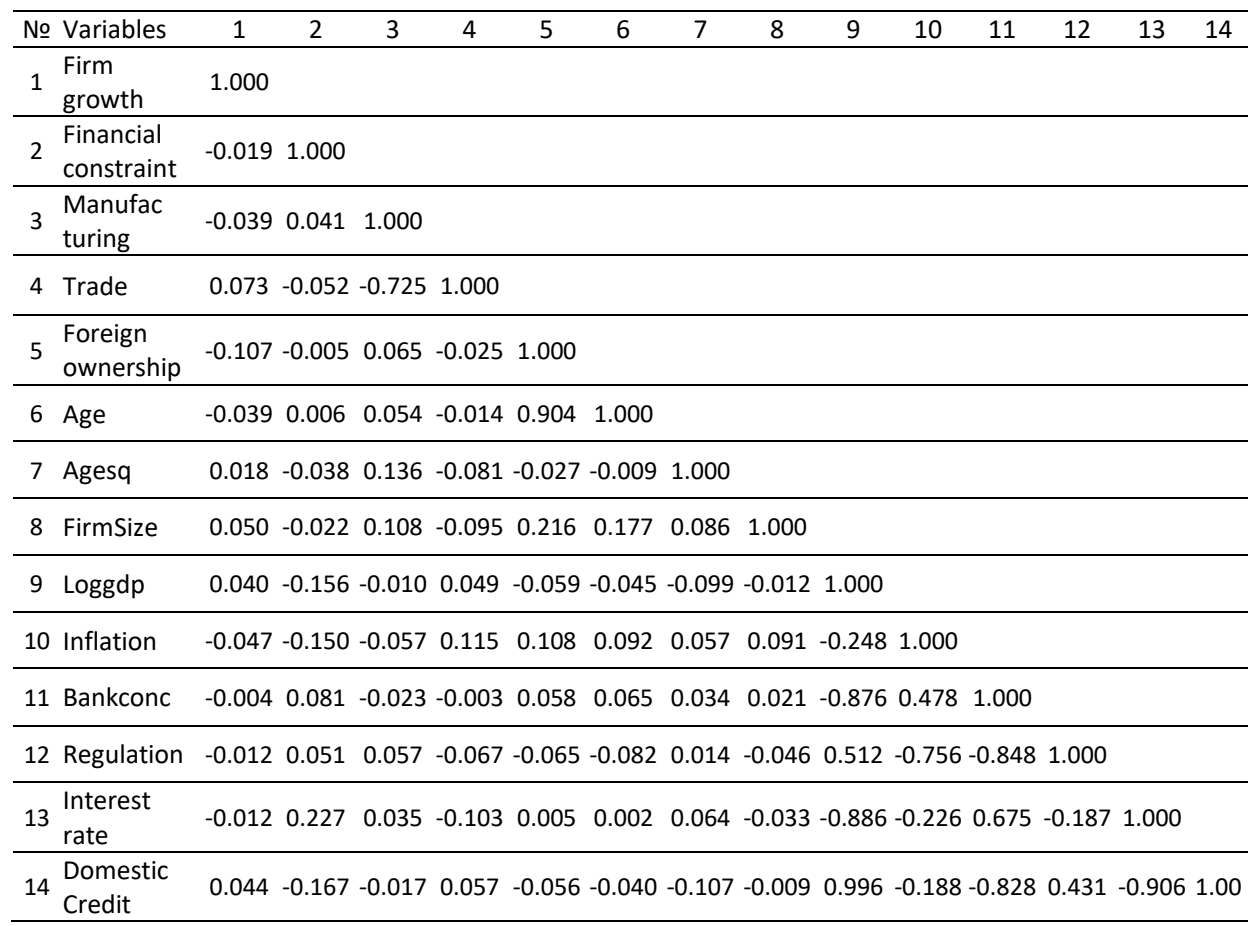

High correlations between country-specific variables were observed. A high negative correlation between Loggdp per capita and bank concentration was found. Regulation indicator negatively and highly correlated with the inflation rate and banking sector concentration. Moreover, the interest rate is highly negatively correlated with the logarithm of per capita GDP and highly positively correlated with banking sector concentration, which means countries with better economic performance have lower interest rates, and the banking sector is less concentrated. Domestic credit is positively highly correlated with Loggdp, and a high negative correlation between bank concentration and domestic credit is caught, which exposes that the credit market is larger in countries with better economic performance and less banking sector concentration. The significantly strong correlation between country-specific variables reveals the high inter-relationship between these variables in the region.

\subsection{Model Specification}

The main interest of the analysis lies in how constraints on access to external financing affect SME growth in terms of employment growth. Firstly, in order to 
examine the factors that financially constrain SMEs, the constraint level was estimated as a function of the firm- and country-specific independent variables. Table 4 presents the definition, expected signs of the explanatory variables, and data sources. Previous studies in the examination of collateral requirements, financing constraints in case of categorical and numerical dependent variable applied the ordered probit, logit, tobit, and OLS regression models, respectively (Barth et al., 2011; Hartarska \& Nadolnyak, 2008). Generally, in previous studies, ordered logit, probit, and tobit models were used with dichotomous dependent variables are either an entity is financially constrained or zero if not.

\section{Table 4. Description of the explanatory variables}

\begin{tabular}{|c|c|c|c|}
\hline Variables & Variable definitions & $\begin{array}{l}\text { Expected } \\
\text { signs }\end{array}$ & $\begin{array}{l}\text { Data } \\
\text { sources }\end{array}$ \\
\hline \multicolumn{4}{|c|}{ Model 1 (Dependent variable: Financial constraint) } \\
\hline \multicolumn{4}{|c|}{ Firm-specific explanatory variables } \\
\hline Manufacturing & Dummy (1 - manufacturing, otherwise -0$)$ & + & BEEPS \\
\hline Trade & $\begin{array}{l}\text { Dummy }(1 \text { - trade sectors (wholesale and } \\
\text { retailing), otherwise - } 0)\end{array}$ & - & BEEPS \\
\hline $\begin{array}{l}\text { Foreign } \\
\text { ownership }\end{array}$ & $\begin{array}{l}\text { Percentage of a firm's shares that belongs to } \\
\text { foreign owners }\end{array}$ & - & BEEPS \\
\hline Age & $\begin{array}{l}\text { Number of years during which an enterprise } \\
\text { has been operating in the selected country }\end{array}$ & $+/-$ & BEEPS \\
\hline Agesq & Square of the Age variable & $+/-$ & BEEPS \\
\hline FirmSize & Number of full-time employees & - & BEEPS \\
\hline \multicolumn{4}{|c|}{ Country-specific explanatory variables } \\
\hline Loggdp & $\begin{array}{l}\text { Logarithm of GDP per capita in current US } \\
\text { dollars }\end{array}$ & - & WDI \\
\hline Inflation & $\begin{array}{l}\text { Annual price change measured by the } \\
\text { consumer price index }\end{array}$ & + & WDI \\
\hline Bankconc & $\begin{array}{l}\text { The assets of the three largest banks as a share } \\
\text { of the assets of all the commercial banks in a } \\
\text { country }\end{array}$ & + & $\begin{array}{l}\text { Financial } \\
\text { Development and } \\
\text { Structure Dataset }\end{array}$ \\
\hline Regulation & Index (between -2.5 and +2.5 ) & - & WGI \\
\hline Interest rate & $\begin{array}{l}\text { Lending interest rates charged by financial } \\
\text { institutions }\end{array}$ & + & $\begin{array}{l}\text { WDI, The Central } \\
\text { Bank of the Republic } \\
\text { of Uzbekistan, } \\
\text { CEIC Database }\end{array}$ \\
\hline $\begin{array}{l}\text { Domestic } \\
\text { Credit }\end{array}$ & $\begin{array}{l}\text { Total domestic credit to the private sector as a } \\
\text { percentage of GDP. }\end{array}$ & - & $\begin{array}{l}\text { Financial Access } \\
\text { Survey }\end{array}$ \\
\hline \multicolumn{4}{|c|}{ Model 2 (Dependent variable: firm growth) } \\
\hline \multicolumn{4}{|c|}{ Explanatory variable } \\
\hline $\begin{array}{l}\text { Financial } \\
\text { constraint }\end{array}$ & $\begin{array}{l}\text { Dummy ( } 1 \text { - access to finance is "major } \\
\text { obstacle" and "very severe obstacle", else 0) }\end{array}$ & $-/+$ & BEEPS \\
\hline \multicolumn{4}{|c|}{ Control variables } \\
\hline \multicolumn{3}{|c|}{$\begin{array}{l}\text { Manufacturing, Trade, Foreign ownership, Age, Agesq, FirmSize, Loggdp, } \\
\text { regulation }\end{array}$} & WDI, WGI \\
\hline
\end{tabular}


Following the way of analysis employed in most of the relevant studies (Barth et al., 2011; Beck et al., 2006), considering the dummy nature of the independent variable (Financial constraint), probit regression was used. Additionally, to test the robustness of the selected independent variables, by changing the dummy values of the financial constraint variable with its ordinal values, the ordered probit regression was run. Even though linear regression analysis is a commonly used method in social science, it assumes a continuous dependent variable. According to Wooldridge (2010), two important shortcomings of the linear probability model are the fitted probabilities can take values of less than zero or greater than one, and the partial effect of any explanatory variable appearing in level form is constant. To deal with these drawbacks of the linear probability model, one of the binary response models - probit is applied. In the binary response model, interest lies primarily in the response probability

$$
P(y=1 \mid x)=P\left(y=1 \mid x_{1}, x_{2}, \ldots, x_{k}\right)
$$

Where $\mathrm{x}$ is used to denote the full set of explanatory variables. In the application of probit model, the main goal is to explain the effects of $x_{k}$ on the response probability $P(y=1 \mid x)$.

For estimating models with the limited dependent variable, the maximum likelihood method is required since it is based on the distribution of $y$ given $x$, the heteroscedasticity in $\operatorname{Var}(y \mid x)$ is automatically accounted for. Under very general conditions, maximum likelihood estimation for a random sample is consistent, asymptotically normal, and efficient (Wooldridge, 2012).

It was assumed that the underlying responses of firms could be described by the following model.

$$
\begin{aligned}
& \text { Financial constraint }=\alpha+\beta \text { Firm }_{\text {characetristics }} \text { ch, }+ \\
& \gamma \text { Country specific determinants }_{k}+\varepsilon_{i, k}
\end{aligned}
$$

where Firm characteristics are a vector of the firm-specific variables are reported by a firm $i$ in country $k$, which includes the industry in which the firm operates (manufacturing or trade), foreign ownership, age, age squared, and the firm size. Country-specific determinants include the logarithm of GDP per capita, indicators for the bank concentration, inflation rate, regulation, domestic credit, and interest rate.

In the second stage, the extent to which obstacles to access to external financing constrained the employment growth of the selected SMEs was analyzed. In addition to financial constraints, the impacts of other firms- and country-specific variables on firm growth were also controlled. The value of the variable inflated factor (VIF), which was 1.43, confirms that the estimation does not suffer from a multicollinearity problem. Furthermore, the Breusch-Pagan/Cook-Weisberg test for constant variances of residuals was performed, and the results confirmed the heteroskedasticity of the error terms. As the data under consideration suffered from heterogeneity problem, in addition to ordinary least squares (OLS) with clustered 
standard errors by country, Feasible Generalized Least Squares (FGLS) specification was applied for employment growth estimates (Wooldridge, 2010).

To observe the prevailing impact of financial constraints and to control for the effects of other selected variables on firm growth, the specification given in Model 2 was employed:

FirmGrowth $=\delta_{0}+\delta_{1}$ Financial constraint $+\delta_{2}$ Manufacturing + $\delta_{3}$ Trade $+\delta_{4}$ ForeignOwnership $+\delta_{5}$ Age $+\delta_{6}$ Agesq $+\delta_{7}$ FirmSize + $\delta_{8}$ LogGDP $+\delta_{9}$ Regulation $+\delta_{10}$ DomesticCredit $_{10}+\epsilon$

Since omitted country-specific factors may cause error terms to be correlated for firms within countries, standard errors were clustered by country. To control for omitted variables bias, country dummies were included in the analysis. Further, the impact of some country-specific factors on the level of financial constraint perception of SMEs was explored. To avoid the multicollinearity problem, the country dummies were replaced with particular country-specific variables, and separate regressions were run with each of them.

\section{Findings and Discussions}

Table 5 presents the percentage of obstacles reported by SMEs in the sample across country groups. The table was constructed based on the responses of SME interviewees that consisted of business owners, co-owners, accountants, and managers to the question "Which of the following elements of the business environment, if any, currently represents the biggest obstacle faced by this establishment?".

\section{Table 5. The Obstacles faced by SMEs in Central Asian Economies}

\begin{tabular}{lc}
\hline Obstacles faced by SMEs & Percentage \\
\hline Access to finance & $9.40 \%$ \\
\hline Access to land & $3.24 \%$ \\
\hline Business licensing and permits & $2.21 \%$ \\
\hline Corruption & $9.72 \%$ \\
\hline Courts & $0.55 \%$ \\
\hline Crime, theft, and disorder & $1.18 \%$ \\
\hline Customs and trade regulations & $3.00 \%$ \\
\hline Electricity & $9.24 \%$ \\
\hline Inadequately educated workforce & $6.71 \%$ \\
\hline Labor regulations & $0.63 \%$ \\
\hline Political instability & $8.53 \%$ \\
\hline Practices of competitors in the informal sector & $12.01 \%$ \\
\hline Tax administration & $2.61 \%$ \\
\hline Tax rates & $10.74 \%$ \\
\hline Transport & $2.37 \%$ \\
\hline Refused to answer/Don't know & $17.75 \%$ \\
\hline Total & $100.00 \%$ \\
\hline
\end{tabular}


In the region, the most highly perceived obstacles reported by SMEs in the sample are practices of competitors in the informal sector, tax rates, corruption, access to electricity, and finance. For SMEs, informal competition is perceived as the biggest obstacle for their operations; $12.01 \%$ of enterprises in the sample report it as the biggest obstacle. Corruption and access to electricity are in the list of the highest obstacles, with $9.72 \%$ and $9.24 \%$ of firms, respectively. As has been observed, access to finance is one of the biggest obstacles for the operations of SMEs in the sample.

\subsection{Determinants of Financing Constraints}

Table $6 \mathrm{~A}$ and $6 \mathrm{~B}$ display the findings of the financial constraints' determinant analysis for the selected SMEs of Central Asian countries. Table 6A and $6 \mathrm{~B}$ report the probit and ordered probit estimates, respectively. The first column of the table presents only the firm-specific factors of the financing constraint perceived by SMEs. It was found that among firm-specific variables, only foreign ownership is negatively significantly associated with perceived financial constraints. First, they can obtain funds from their parent organizations, which are mostly located in developed economies.

Table 6A. Determinants of financing constraints faced by SMEs

\begin{tabular}{|c|c|c|c|c|c|c|c|}
\hline Financial constraint & $(1)$ & $(2)$ & (3) & $(4)$ & $(5)$ & $(6)$ & $(7)$ \\
\hline Manufacturing & $\begin{array}{c}0.127 \\
(0.149) \\
\end{array}$ & $\begin{array}{c}0.089 \\
(0.129) \\
\end{array}$ & $\begin{array}{c}0.073 \\
(0.139) \\
\end{array}$ & $\begin{array}{c}0.064 \\
(0.128) \\
\end{array}$ & $\begin{array}{c}0.046 \\
(0.116) \\
\end{array}$ & $\begin{array}{c}0.121 \\
(0.143) \\
\end{array}$ & $\begin{array}{c}0.093 \\
(0.132) \\
\end{array}$ \\
\hline Trade & $\begin{array}{c}-0.004 \\
(0.133) \\
\end{array}$ & $\begin{array}{c}-0.120 \\
(0.116) \\
\end{array}$ & $\begin{array}{l}-0.072 \\
(0.148) \\
\end{array}$ & \begin{tabular}{|l|}
-0.139 \\
$(0.101)$ \\
\end{tabular} & $\begin{array}{c}-0.139 \\
(0.095) \\
\end{array}$ & $\begin{array}{c}-0.040 \\
(0.132) \\
\end{array}$ & $\begin{array}{c}-0.102 \\
(0.116) \\
\end{array}$ \\
\hline Age & $\begin{array}{c}-0.012 \\
(0.012)\end{array}$ & $\begin{array}{l}-0.014 \\
(0.013) \\
\end{array}$ & $\begin{array}{l}-0.005 \\
(0.016) \\
\end{array}$ & $\begin{array}{l}-0.010 \\
(0.016) \\
\end{array}$ & $\begin{array}{c}-0.011 \\
(0.016)\end{array}$ & $\begin{array}{l}-0.011 \\
(0.012) \\
\end{array}$ & $\begin{array}{c}-0.015 \\
(0.013) \\
\end{array}$ \\
\hline Agesq & $\begin{array}{c}0.002 \\
(0.001) \\
\end{array}$ & $\begin{array}{c}0.002 \\
(0.001) \\
\end{array}$ & $\begin{array}{c}0.001 \\
(0.001) \\
\end{array}$ & $\begin{array}{c}0.001 \\
(0.001) \\
\end{array}$ & $\begin{array}{c}0.002 \\
(0.001) \\
\end{array}$ & $\begin{array}{c}0.002 \\
(0.001) \\
\end{array}$ & $\begin{array}{c}0.001 \\
(0.000) \\
\end{array}$ \\
\hline Foreignownership & $\begin{array}{c}-0.005 \\
(0.001)^{* * *}\end{array}$ & $\begin{array}{c}-0.005 \\
(0.002)^{* * *}\end{array}$ & $\begin{array}{c}-0.003 \\
(0.002)^{*}\end{array}$ & $\begin{array}{c}-0.004 \\
(0.003)^{* *}\end{array}$ & $\begin{array}{c}-0.004 \\
(0.002)^{*}\end{array}$ & $\begin{array}{c}-0.005 \\
(0.002)^{* * *}\end{array}$ & $\begin{array}{c}-0.006 \\
(0.002)^{* * *}\end{array}$ \\
\hline Firmsize & $\begin{array}{c}-0.002 \\
(0.001)\end{array}$ & $\begin{array}{c}-0.001 \\
(0.001)\end{array}$ & $\begin{array}{c}-0.001 \\
(0.001) \\
\end{array}$ & $\begin{array}{c}-0.001 \\
(0.001) \\
\end{array}$ & $\begin{array}{c}-0.001 \\
(0.001) \\
\end{array}$ & $\begin{array}{c}-0.001 \\
(0.001)\end{array}$ & $\begin{array}{c}-0.001 \\
(0.001)\end{array}$ \\
\hline Loggdp & & $\begin{array}{c}-0.558 \\
(0.179)^{* * *}\end{array}$ & & & & & \\
\hline Inflation & & & $\begin{array}{c}-0.119 \\
(0.042)^{* * *}\end{array}$ & & & & \\
\hline Bankconc & & & & $\begin{array}{c}0.005 \\
(0.007)\end{array}$ & & & \\
\hline Regulation & & & & & $\begin{array}{c}0.163 \\
(0.397) \\
\end{array}$ & & \\
\hline Interest rate & & & & & & $\begin{array}{c}0.078 \\
(0.016)^{* * *} \\
\end{array}$ & \\
\hline Domestic credit & & & & & & & $\begin{array}{c}-0.031 \\
(0.009)^{* * *}\end{array}$ \\
\hline Country dummy & Yes & & & & & & \\
\hline _cons & $\begin{array}{l}-1.637 \\
(0.158) \\
\end{array}$ & $\begin{array}{c}1.006 \\
(0.706)\end{array}$ & $\begin{array}{l}-0.247 \\
(0.410)\end{array}$ & $\begin{array}{c}-1.326 \\
(0.352)^{* * *}\end{array}$ & $\begin{array}{c}-0.810 \\
(0.312)^{* * *}\end{array}$ & $\begin{array}{c}-2.431 \\
(0.481)^{* * *}\end{array}$ & $\begin{array}{c}-0.192 \\
(0.282)\end{array}$ \\
\hline No of obs. & 1,258 & 1,258 & 1,258 & 1,258 & 1,258 & 1,258 & 1,258 \\
\hline Pseudo R-sq & 0.086 & 0.042 & 0.039 & 0.016 & 0.011 & 0.071 & 0.047 \\
\hline Log likelihood & -446.867 & -468.292 & -469.843 & -480.782 & -483.527 & -454.157 & -465.766 \\
\hline
\end{tabular}


Table 6B. Determinants of financing constraints faced by SMEs

\begin{tabular}{|c|c|c|c|c|c|c|c|}
\hline Financial constraint & (8) & (9) & (10) & (11) & $(12)$ & $(13)$ & (14) \\
\hline Manufacturing & $\begin{array}{c}0.075 \\
(0.168) \\
\end{array}$ & $\begin{array}{c}0.040 \\
(0.158)\end{array}$ & $\begin{array}{c}0.055 \\
(0.167) \\
\end{array}$ & $\begin{array}{c}0.021 \\
(0.163) \\
\end{array}$ & $\begin{array}{c}0.024 \\
(0.155) \\
\end{array}$ & $\begin{array}{c}0.066 \\
(0.163) \\
\end{array}$ & $\begin{array}{c}0.044 \\
(0.157) \\
\end{array}$ \\
\hline Trade & $\begin{array}{c}-0.070 \\
(0.109)\end{array}$ & $\begin{array}{c}-0.170 \\
(0.099)^{*}\end{array}$ & $\begin{array}{c}-0.092 \\
(0.122)\end{array}$ & $\begin{array}{c}-0.185 \\
(0.077)^{* *}\end{array}$ & $\begin{array}{c}-0.160 \\
(0.081)^{* *}\end{array}$ & $\begin{array}{c}-0.127 \\
(0.110)\end{array}$ & $\begin{array}{c}-0.165 \\
(0.101)\end{array}$ \\
\hline Age & $\begin{array}{c}-0.006 \\
(0.012)\end{array}$ & $\begin{array}{c}-0.007 \\
(0.012)\end{array}$ & $\begin{array}{c}0.001 \\
(0.013)\end{array}$ & $\begin{array}{c}-0.006 \\
(0.012)\end{array}$ & $\begin{array}{c}-0.007 \\
(0.011)\end{array}$ & $\begin{array}{c}-0.007 \\
(0.010)\end{array}$ & $\begin{array}{c}-0.007 \\
(0.011)\end{array}$ \\
\hline Agesq & $\begin{array}{c}0.001 \\
(0.001) \\
\end{array}$ & $\begin{array}{c}0.001 \\
(0.000) \\
\end{array}$ & $\begin{array}{c}0.010 \\
(0.000) \\
\end{array}$ & $\begin{array}{c}0.001 \\
(0.000)\end{array}$ & $\begin{array}{c}0.001 \\
(0.000) \\
\end{array}$ & $\begin{array}{c}0.001 \\
(0.000)\end{array}$ & $\begin{array}{c}0.001 \\
(0.000) \\
\end{array}$ \\
\hline Foreignownership & $\begin{array}{c}-0.002 \\
(0.001)^{* *}\end{array}$ & $\begin{array}{c}-0.001 \\
(0.002) \\
\end{array}$ & $\begin{array}{c}0.001 \\
(0.001) \\
\end{array}$ & $\begin{array}{c}-0.001 \\
(0.002) \\
\end{array}$ & $\begin{array}{c}-0.001 \\
(0.001)\end{array}$ & $\begin{array}{c}-0.002 \\
(0.001) \\
\end{array}$ & $\begin{array}{l}-0.002 \\
(0.001) \\
\end{array}$ \\
\hline Firmsize & $\begin{array}{c}-0.001 \\
(0.001)^{* * *}\end{array}$ & $\begin{array}{c}-0.002 \\
(0.000)^{* * *}\end{array}$ & $\begin{array}{c}-0.001 \\
(0.000)^{* * *}\end{array}$ & $\begin{array}{c}-0.002 \\
(0.000)^{* * *}\end{array}$ & $\begin{array}{c}-0.002 \\
(0.001)^{* * *}\end{array}$ & $\begin{array}{c}-0.002 \\
(0.000)\end{array}$ & $\begin{array}{l}-0.002 \\
(0.000)\end{array}$ \\
\hline Loggdp & & $\begin{array}{c}-0.099 \\
(0.213)\end{array}$ & & & & & \\
\hline Inflation & & & $\begin{array}{c}-0.131 \\
(0.015)^{* * *}\end{array}$ & & & & \\
\hline Bankconc & & & & $\begin{array}{l}-0.003 \\
(0.006)\end{array}$ & & & \\
\hline Regulation & & & & & $\begin{array}{c}0.460 \\
(0.243)^{*}\end{array}$ & & \\
\hline Interest rate & & & & & & $\begin{array}{c}0.037 \\
(0.020)^{* *}\end{array}$ & \\
\hline Domestic credit & & & & & & & $\begin{array}{c}-0.008 \\
(0.010)^{*}\end{array}$ \\
\hline Country dummy & Yes & & & & & & \\
\hline /cut1 & $\begin{array}{c}0.707 \\
(0.198) \\
\end{array}$ & $\begin{array}{c}-0.401 \\
(0.892) \\
\end{array}$ & $\begin{array}{c}-0.829 \\
(0.092) \\
\end{array}$ & $\begin{array}{c}-0.260 \\
(0.243) \\
\end{array}$ & $\begin{array}{c}-0.384 \\
(0.079) \\
\end{array}$ & $\begin{array}{c}0.626 \\
(0.621) \\
\end{array}$ & $\begin{array}{l}-0.245 \\
(0.390) \\
\end{array}$ \\
\hline /cut2 & $\begin{array}{c}1.163 \\
(0.106) \\
\end{array}$ & $\begin{array}{c}0.033 \\
(0.868)\end{array}$ & $\begin{array}{c}-0.377 \\
(0.084) \\
\end{array}$ & $\begin{array}{c}0.176 \\
(0.302)\end{array}$ & $\begin{array}{c}0.062 \\
(0.153)\end{array}$ & $\begin{array}{c}1.064 \\
(0.521) \\
\end{array}$ & $\begin{array}{c}0.190 \\
(0.351)\end{array}$ \\
\hline /cut3 & $\begin{array}{c}1.729 \\
(0.119)\end{array}$ & $\begin{array}{c}0.576 \\
(0.916)\end{array}$ & $\begin{array}{c}0.179 \\
(0.163)\end{array}$ & $\begin{array}{c}0.713 \\
(0.327)\end{array}$ & $\begin{array}{c}0.606 \\
(0.254)\end{array}$ & $\begin{array}{c}1.619 \\
(0.463)\end{array}$ & $\begin{array}{c}0.735 \\
(0.400)\end{array}$ \\
\hline /cut4 & $\begin{array}{c}2.607 \\
(0.134)\end{array}$ & $\begin{array}{c}1.419 \\
(0.853)\end{array}$ & $\begin{array}{c}1.035 \\
(0.175)\end{array}$ & $\begin{array}{c}1.546 \\
(0.389)\end{array}$ & $\begin{array}{c}1.450 \\
(0.194)\end{array}$ & $\begin{array}{c}2.480 \\
(0.480)\end{array}$ & $\begin{array}{c}1.581 \\
(0.346)\end{array}$ \\
\hline No of obs. & 1,25 & 1,258 & 1,258 & 1,258 & 1,258 & 1,258 & 1,258 \\
\hline Pseudo R-sq & 0.039 & 0.010 & 0.031 & 0.010 & 0.021 & 0.013 & 0.010 \\
\hline Log likelihood & -1489.537 & -1541.397 & -1501.777 & -1539.790 & -1517.425 & -1528.887 & -1539.989 \\
\hline
\end{tabular}

Second, foreign-owned SMEs even apply for loans in developing countries; also, to meet the requirements of their head companies, they have more accurate financial statements, which provide "hard information" that makes it easier for banks to evaluate their creditworthiness. The estimates of probit regression displayed the insignificant relation between size and financing constraint, which supports the findings of Hashi and Krasniqi (2011). Since the sample includes only SMEs with a maximum of 250 full-time employees, the statistically insignificant association between firm size and financial constraint levels of SMEs implies that both small and medium-sized firms are affected by almost the same factors. However, the outcomes of the ordered probit regression where the financial constraint is 
measured with ordinal values ranging between 0 and 4 showed a statistically significant negative connection in Central Asia. Such finding is in line with a common view of small firms' being financially more constrained in comparison to their larger counterparts.

In the next regressions, presented in columns 2-7 of Tables 6A, in addition to firm characteristics, the country-specific variables that might influence the SMEs' perceptions of financial constraints were tested. In Central Asian economies, both Loggdp per capita and inflation are significantly negatively associated with financial constraints. The negative association between per capita GDP and financial constraint is in line with relevant literature. It has been found that firms operating in economies with a higher level of GDP per capita report lower financing constraints. Since SMEs mainly rely on internal funds, within the theoretical framework, profitable smaller firms perceive finance as less constraining. For instance, in the Central Asian sample, Kazakhstan has the highest GDP per capita, US dollar $13,890.86$, while in the other three countries, it is significantly low (followed by US dollars 1,907.55 in Uzbekistan). Respectively, Kazakhstan has lower bank concentration, interest rate, inflation, and a larger credit market, which enables more development of the private sector and easing access to credit for firms.

The negative relationship between financial constraint and inflation rate in Central Asian economies opposes previous findings. Although it has been indicated that in a high inflationary environment, firms are expected to be financially more constrained to justify the negative relationship in the region, the following arguments are provided. Even though the inflation rate had been retained high in the post-crisis period, the Uzbek Government has injected large doses of capital into the banking system (International Group of Rating Agencies, 2018). In the first nine months of 2011, as a result of capital injection by the Central Bank of Uzbekistan, the aggregate capital of the banks grew from USD2.3 billion on January 1 to USD2.6 billion on October 1 , which was a $14 \%$ increase in aggregate banking sector capital. According to the President's Decree on "The Priority Directions of Further Reforming and Increasing the Sustainability of the Financial and Banking System of the Country in 2011-2015 and Achievement of High International Rating Figures", capital of banks was increased by 2.5 times during 2011-2015 (European Investment Bank, 2012).

Moreover, due to less integration with European and other developed financial systems, in Central Asia, especially in Uzbekistan, banking sectors' exposure to global risk was limited. Banks benefited from the large capital injections by the Government after the global crisis increased their resilience to shocks (World Bank, 2012). Although such government intervention strengthened the role of the Government and reduced the independence of banks, the amount of credit to firms increased, which made business enterprises less financially constrained in comparison to their counterparts operating in other economies.

Despite high banking sector concentration, in Central Asia, an insignificant association between SMEs' financial constraint perception and banking sector 
concentration was found. It may be argued that the true economic relationship between banking sector consolidation and the financial constraint level of small firms had been distorted by political instability and government intervention in the banking sector in the region. The governments of both countries with the highest banking sector concentration indicator, Uzbekistan and Tajikistan, provided a large number of capital injections to the financial sector. As mentioned above, because of state injections, in Uzbekistan, the capital of banks was expected to increase 2.5 times during the 2011-2015 years. The increase in bank capital fueled the rapid increase in bank loans. Although 'directed loans' to state-owned enterprises increased substantially, credit to the private sector increased by $20 \%$. In Uzbekistan, in accordance with the government program "The Year of Small Business and Entrepreneurship," the volume of loans to SMEs during the first three quarters of 2011, compared to the same period in 2010, increased by 1.5 times (European Investment Bank, 2012). According to the financial system assessment of the International Monetary Fund (IMF), the banking sector of Tajikistan also suffers from the legacy of directed lending. Due to government liquidity provision to banks in 2014, the Tajik economy experienced a credit boom (IMF, 2016).

In addition to the above-mentioned distortions to banking structure -SME financing pattern, levels of financial depth, financial inclusion, and financial literacy in the region also may interpret the statistically insignificant relationship between banking sector consolidation and financial constraint perception of small firms in Central Asia. Morgan, Zhang, and Kydyrbayev (2018) argued that the possession of accounts at a formal financial institution, including commercial banks, credit unions, micro finances, cooperative or other institutions is an important determinant of access to finance. Moreover, they evidenced although there are strong arguments in favor of a higher level of financial inclusion for economic development, that in Central Asian economies, because of disruptions and instabilities following the break-ups, financial inclusion has been significantly lagged than other developing economies. The main reasons for this trend are the population's lack of trust toward financial institutions and Government and a low level of financial literacy. Moreover, the authors also argued that cultural, traditional, and religious factors also play an important role in the usage of credit.

Financial literacy is another challenge for most small business owners and policymakers alike. Even though this area has limited data, according to Global Financial Literacy Survey in 2014, as cited in Morgan et al. (2018), Central Asian economies have been among countries with the lowest level of financial literacy. For instance, in Kyrgyzstan, a high percentage of the population is not interested in acquiring information about financial services and financial markets, and the share of families with trouble making ends because of credits is high.

Although it was assumed that a better private-sector regulatory environment mitigates the financial constraint of small firms, no significant association between the regulation and the financial constraint level of SMEs was found in the selected 
Central Asian economies. There is also a lack of communication between the business sector and government regulators about their different perceptions of reform success and its feasibility. The bottlenecks related to regulative enforcement are other concerns that require regulators to be engaged in a more regular dialogue with entrepreneurs and other stakeholders, to learn their real needs and obstacles, and to adjust policies, regulative and legal tools so that they facilitate the development of the private sector. Moreover, particular bank regulation and supervision measurement, which was not available, would have a significant relationship with the financial constraints of SMEs rather than regulation indicators of the general private sector. In most of the countries in the sample, central banks are responsible for supervision, regulation, and licensing of financial institutions; they are in charge of issuing normative acts for financial institutions and request reports (Morgan et al., 2018).

The interest rate is significantly associated with the financial constraint levels of SMEs in the region. Such a finding is in line with recent findings in the literature. It has been consistently found that the young age and opaqueness of small firms lead potential creditors to charge high interest rates, which makes them mostly limit with internal funds. Although bank credit is the most common type of external financing for SMEs, the interest rate is one of the reasons why they don't apply for bank loans.

As reported in columns 7 and 14 of Table 6B, the larger domestic credit market is associated with less financial constraint perception of SMEs. This outcome makes sense both theoretically and practically. Economies with developed credit markets are able to provide more financial alternatives for firms. In emerging economies, where the equity market is under-developed, small firms mostly rely on short-term debts (Kumar \& Rao, 2015). Hence, in developing countries, a more efficient debt market provides better credit opportunities, and it is an important country-specific indicator that has a significant role in SME financing. As evidenced in the relevant literature, bank credit is an important source of external financing for SMEs, and a higher share of bank loans provided as a percentage of GDP makes financial obstacles less constraining. Therefore, establishments operating in countries with a higher level of credit as a percentage of GDP report lower financial obstacles.

\subsection{Regression Outcomes for Firm Growth}

Table 7 presents the estimates of the determinants of firm growth. For each of OLS and FGSL, as reported in the table, firm-specific estimates with country dummies and coefficients of firm-specific variables together with country-specific controls were given as outcomes of different regressions separately. The results of the OLS and FGLS regressions highlight that the relationship between financial constraint and firm growth is statistically not significant in Central Asia. No significant relationship between financial constraint and firm growth was found in Central Asian economies, which is in line with the findings of Saeed (2009), Allen et al. (2012), and Beck et al. (2015). The possible interpretation for such a finding is that access to finance will not 
have a positive impact on firm growth unless the credit market recovers from systematic allocative inefficiency. In economies with weak regulation of the financial market, the existing fund is allocated to politically connected enterprises with a low marginal return to investment (Regasa et al., 2019). Financial reforms have a growthenhancing impact on the economy if only efficient banking sector regulation will be provided (Demetriades \& Rousseau, 2016).

\section{Table 7. Regression results for Firm Growth}

\begin{tabular}{|c|c|c|c|c|}
\hline \multirow{3}{*}{$\begin{array}{l}\text { Firm growth } \\
\text { Financial constraint }\end{array}$} & \multicolumn{2}{|c|}{ OLS } & \multicolumn{2}{|c|}{ FGLS } \\
\hline & -0.003 & -0.002 & -0.003 & -0.002 \\
\hline & $(0.006)$ & $(0.005)$ & $(0.006)$ & $(0.005)$ \\
\hline \multirow{2}{*}{ Manufacturing } & 0.0040 & 0.033 & 0.0040 & 0.033 \\
\hline & $(0.002)$ & $(0.002)$ & $(0.002)$ & $(0.002)$ \\
\hline \multirow{2}{*}{ Trade } & 0.0110 & 0.001 & 0.0110 & 0.001 \\
\hline & $(0.005)$ & $(0.004)^{*}$ & $(0.005)$ & $(0.004)^{*}$ \\
\hline \multirow{2}{*}{ Age } & -0.0022 & -0.002 & -0.0022 & -0.002 \\
\hline & $(0.001)^{*}$ & $(0.007)^{* *}$ & $(0.001)^{*}$ & $(0.007)^{* *}$ \\
\hline \multirow{2}{*}{ Agesq } & 0.001 & 0.001 & 0.001 & 0.001 \\
\hline & $(0.000)^{* *}$ & $(0.000)^{*}$ & $(0.000)^{* *}$ & $(0.000)^{*}$ \\
\hline \multirow{2}{*}{ Foreign ownership } & 0.001 & 0.010 & 0.001 & 0.010 \\
\hline & $(0.001)$ & $(0.001)$ & $(0.001)$ & $(0.001)$ \\
\hline \multirow{2}{*}{ Firm size } & 0.001 & 0.001 & 0.001 & 0.001 \\
\hline & $(0.001)^{* * *}$ & $(0.000)^{* * *}$ & $(0.001)^{* * *}$ & $(0.000)^{* * *}$ \\
\hline \multirow{2}{*}{ Loggdp } & & 0.004 & & 0.004 \\
\hline & & $(0.006)$ & & $(0.006)$ \\
\hline \multirow{2}{*}{ Regulation } & & -0.002 & & -0.002 \\
\hline & & $(0.006)$ & & $(0.006)$ \\
\hline Country dummy & Yes & & Yes & \\
\hline \multirow[b]{2}{*}{ _cons } & 0.017 & 0.011 & 0.017 & 0.011 \\
\hline & $(0.009)$ & $(0.036)$ & $(0.009)$ & $(0.036)$ \\
\hline No of observations & 1,258 & 1,258 & 1,258 & 1,258 \\
\hline R-squared & 0.053 & 0.044 & 0.053 & 0.044 \\
\hline
\end{tabular}

Note: clustered standard errors by country are given in parentheses; ${ }^{*}$ indicates the significance of the coefficient at $10 \% ; * *$ and $* * *$ indicate the significance of the coefficients at $5 \%$ and $1 \%$, respectively

Ruziev and Midmore (2015) argued that in post-Soviet economies, political authorities affect economic outcomes both formally and informally through inefficient rules, regulations, and interventions and interpersonal and individual political connections. Entrenched political authorities affect the operations of small businesses by setting regulations, administrative rules to protect their own interests. Consequently, such practices create an unfavorable business environment and obstacles for enterprises. Furthermore, inefficient regulation and increasing bureaucracy lead to reinforcement of bribery and favoritism. Most former Soviet Union economies, including Central Asian countries, have been suffering from an organizational failure, and bureaucracy has gained importance. Since being politically connected and interpersonal network is considered as an important asset for running a business, individuals lose motive to obey regulative legislation. They resort to interpersonal connections, which leads to misallocation of resources. Studying the use of informal finance by SMEs in Uzbekistan, Ruziev and Midmore 
(2015) found that more percentage of politically connected SMEs obtained commercial bank loans, but a smaller percentage of them reported growth since their inception than their counterparts without government connection. Moreover, the authors recognized that SMEs with political connections are more than twice as likely to receive a bank loan than enterprises without connections. These findings reveal that in Central Asian economies with weak institutional development, due to the active functioning of interpersonal relations, even the limited share of the formal fund left to the private sector is distributed unequally, leaving businesses with political connections disproportionately more advantaged.

According to the private sector assessment report of Asian Development Banks (ADB) in 2013, the Kyrgyz business environment discourages entrepreneurs, investors, as well as creditors. They are all concerned about the potential for agreements and contractual obligations to be renounced and breached unfairly. This lack of trust is the main reason why enterprises prefer to be engaged in short-term business turnover cycles, to act informally, and why creditors unwilling to lend to small, unfamiliar enterprises.

Holzhacker (2018) indicated that in Uzbekistan, access to the finance of SMEs had been distorted by state-directed lending. The preferential access of governmentconnected business entities to resources, including financing, leaves the private sector disadvantaged and averts them from exploiting their full capacity. The main problem that impedes SME growth is the presence of a strong government role in the economy.

SMEs operating in the trade sector in Central Asia report weakly significant growth; whereas, SMEs operating in the manufacturing sector did not report statistically employment growth. Although the manufacturing industry is comparatively more labor-intensive, due to other growth-constraining obstacles, SMEs operating in this sector did not exhibit employment growth. The statistically insignificant relationship between firm growth and industry is in line with previous findings of Fernández et al. (2019), Krasniqi (2012), and Mateev and Anastasov (2010). Fernández et al. (2019) argued that firm attributes have greater weight than the industry effect in interpreting firm performance. The significant growth reporting of Central Asian SMEs operating in the trade sector may be interpreted by the following facts. Since the early 2000s, the trade volume between China and Central Asian economies is tripled, where small establishments account for the bulk of that tight trade relationship (Raballand \& Andrésy, 2007). In 2006, a trade treaty was signed between Kazakhstan and China, and several free economic zones were established on the borders. According to the treaty, importers from Kazakhstan are allowed to enter these zones visa-free, which made Chinese goods easy to access for entrepreneurs. Moreover, in order to support trade relationships, four China-Kazakhstan connecting road routes (Urumchi-Dostyk-Karaganda, Urumchi-Khorgos-Karaganda, UrumchiMaikapchagay-Karaganda, and Urumchi-Baketu-Karaganda) were built (Suvankulov \& Guc, 2012). 
In Central Asia, open market places - "bazaars" have a significant role in the retail trade sector, especially for consumer goods. The retail trade sector of Kyrgyzstan plays a pivotal role in re-distributing imported Chinese goods across other Central Asian economies and Russia. The dramatic increase in imports after 2006 was enabled by trade-friendly custom regulations of Kyrgyzstan since it provided readyto-order conditions for Kyrgyz importers. More specifically, goods imported to Kyrgyzstan were subject to low flat tariffs duties, and tariff calculations were based on the volume of goods rather than their value. Consequently, in the pre-crisis period, according to the mirror trade figure, the volume of unreported import volume into Kyrgyzstan was five times higher than it was in 2004 (Kaminski \& Raballand, 2009).

Mogilevskii (2012) indicated that re-export activities are an important source of income and a vital sector of the Kyrgyz economy. The re-export developed by efforts of the private sector that exploited the trade-friendly government regulations, and it has been the main source of employment. Almost $70 \%$ of all imported goods into Kyrgyzstan were not sold to domestic end-consumers; they had been resold to traders in other Central Asian countries and Russia. For instance, in the Kara-Suu open market in the southern part of Kyrgyzstan, 65-75\% of all imported products have been re-exported to Uzbekistan, $10-15 \%$ to Tajikistan.

Such agreements between economies, trade-friendly government regulations, infrastructure have led to activate trading activities in Central Asian countries. Consequently, small firms engaged in the trade may have been expanded, whereas, because of a fierce informal competition, weak competitive advantages, enterprises in the manufacturing sector are not able to grow.

It was found that age has a statistically negative impact on firm growth in Central Asia. Also, non-linearity in the relationship between age and growth can be observed. These findings are similar to the findings of Xheneti and Bartlett (2012) and Nizaeva and Coskun (2019) in the case of other transition, developing economies. SMEs mostly rely on internal sources of financing; hence, it is worth discussing that the financial constraint levels of small firms might depend on their growth stage. Most SME owners raise their initial capital from personal sources, relatives, and friends, and in their early years, they may also be able to finance their initial expansions to some extent with internal sources. However, since internal financing is not adequate for continuous expansions, and external sources are usually not available, as firms mature, they perceive access to financing as more of a major obstacle. Accordingly, older firms report a low firm growth rate.

The association between foreign ownership and firm growth is not significant for Central Asian countries. Foreign-owned firms may prefer not to grow due to other factors, such as limited market opportunities, administrative and legal constraints, or macroeconomic and political instabilities in the selected developing countries 
The results show that larger firms report higher growth rates in Central Asia. Although firm size did not have a significant effect on the financial constraint levels of the firms in the selected economies, they possess more bargaining power and more social and political connections, which enable them to overcome growthconstraining obstacles and may have facilitated their growth.

GDP per capita and regulation don't have a statistically significant association with firm growth. In the literature, there is no consistent evidence that associates a large SME sector with income growth in low-income countries (Beck et al., 2005) because the link between the SME sector and economic development is distorted by the institutional efficiency levels of the countries. Even in countries with relatively larger economies and higher per capita income, due to low regulatory or institutional policy efficiency levels, the SME sector may be stagnant or adversely affected because inefficient regulatory policies dampen competition and negatively affect firm growth.

\section{Conclusion}

In this study, the firm and country-specific factors that affect the access to external finance of SMEs and the relationship between financial constraint and firm growth in Central Asian emerging economies were investigated. The contributions of this study to the existing literature are twofold. First, while in the relevant literature, the financial constraint of small firms and finance-growth relations have been examined, there is a lack of research that has undertaken a combined analysis of financial constraint determinants and the effect of difficulties in access to finance on growth. Moreover, the provision of interpretations and implications specific to the Central Asian region has important theoretical and practical contributions since, to the best of our knowledge, there is no such study in the case of Central Asia. As a response to these gaps in the literature, the research purposes of undertaking difficulties in SME financing and their impact on firm growth in the developing region.

For the purpose of this study, a two-staged empirical analysis was employed. Firstly, the financial constraint was estimated by probit and ordered probit regressions as a function of a set of determinants. In the second stage, the relationship between firm growth and financial constraint was examined, and the effects of other firm features and country-specific problems on growth were also tested. The firm-level data used in the analysis is obtained from BEEPS $V$, and country-level data acquired from national and international sources that provide cross-country datasets.

The findings of the study imply that in the selected emerging economies, countryspecific factors are more likely to affect access to external finance of SMEs than firmspecific determinants. In Central Asia, it was found that among firm-specific factors, only foreign ownership is significantly related to financing constraint perception of SMEs. Among country-level variables, loggdp per capita and inflation are negatively significantly associated with financing constraints. Even though the negative relationship between inflation rate and financing constraint is inconsistent with the 
literature, it was backed up with the fact that in the high inflationary period private sector in some of the Central Asian economies received a large amount of capital injection from the Government. In Central Asia, the relationship between regulation, financing constraint perception, and banking sector concentration was insignificant. The interest rate is positive, and the domestic credit market is negatively related to financing constraints. Although commercial banks are the primary external fund suppliers for SMEs, the high lending rate is the reason why they don't apply for loans. Since in the selected economies, equity markets are underdeveloped, the larger domestic credit market is associated with, the less financial perception of SMEs. In Central Asia, the insignificant relationship between growth and financing constraint was justified with systematic inefficient fund allocations, the privilege of political connectedness, government-directed lending, and other relevant factors.

The analysis of the study is subject to some limitations that are also common in SME financing research. First, the study used secondary data collected by selfadministered survey, and financial constraint levels were assessed as self-reported responses of SME owners or managers. Data collected by such methodology might be vulnerable to perceptions of respondents and may lead to more subjective findings rather than data from financial statements of firms. Second, the proxy for private sector regulation was acquired from survey-based responses that may be affected by biased perceptions or exaggerations. Despite these shortcomings, the study used databases that provide the most recent available country-specific and enterprise-level data and employed empirical methodologies with caution. Since SMEs have an important contribution to economic development, and they are the main employers, the findings of the research provide great value to SME sector development policies of the selected emerging economies.

\section{References}

ADB. (2013). Private Sector Assessment Update. The Kyrgyz Republic. Mandaluyong City, Philippines: Asian Development Bank.

Allen, F., Chakrabarti, R., De, S., Qian, J. Q., \& Qian, M. (2012). Financing firms in India. Journal of Financial Intermediation, 21(3), 409-445. https://doi.org/10.1016/i.jfi.2012.01.003

Antoun, R., Coskun, A., \& Youssef, D. (2021). Bank-Specific, Macroeconomic, and Institutional Factors Explaining the Capital Buffer and Risk Adjustments in Banks: A Simultaneous Approach. $\begin{array}{lll}\text { Eastern European } \quad \text { Economics, } & \text { 59(2), }\end{array}$ https://doi.org/10.1080/00128775.2020.1870406

Ayyagari, M., Demirgüç-Kunt, A., \& Maksimovic, V. (2008). How Important Are Financing Constraints? The Role of Finance in the Business Environment. The World Bank Economic Review, 22(3), 483-516. https://doi.org/10.1093/wber//hn018

Ayyagari, M., Demirguc-Kunt, A., \& Maksimovic, V. (2014). Who creates jobs in developing countries? Small Business Economics, 43(1), 75-99. https://doi.org/10.1007/s11187-014$\underline{9549-5}$

Ayyagari, M., Demirguc-Kunt, A., \& Maksimovic, V. (2016). Institutions, Firm Financing, and Growth. Economic Development Working Paper Series, No 16/06. 
https://edi.opml.co.uk/wpcms/wp-content/uploads/2016/08/EDI-PF-PAPER-06.2-DemigurcKunt-et-al.pdf

Barth, J. R., Lin, D., \& Yost, K. (2011). Small and Medium Enterprise Financing in Transition Economies. Atlantic Economic Journal, 39(1), 19-38. https://doi.org/10.1007/s11293-010$\underline{9260-0}$

Beck, T., \& Demirguc-Kunt, A. (2006). Small and medium-size enterprises: Access to finance as a growth constraint. Journal of Banking \& Finance, 30(11), 2931-2943. https://doi.org/10.1016/i.jbankfin.2006.05.009

Beck, T., Demirgüç-Kunt, A., \& Honohan, P. (2009). Access to Financial Services: Measurement, Impact, and Policies. The World Bank Research Observer, 24(1), 119-145. https://doi.org/10.1093/wbro/lkn008

Beck, T., Demirguc-Kunt, A., \& Maksimovic, V. (2005). Financial and Legal Constraints to Growth: Does Firm Size Matter? The Journal of Finance, 60(1), 137-177. https://doi.org/10.1111/j.1540-6261.2005.00727.x

Beck, T., Demirguc-Kunt, A., \& Martinez Peria, M. S. (2008). Bank financing for SMEs around the world: Drivers, obstacles, business models, and lending practices. The World Bank.

Beck, T., Lu, L., \& Yang, R. (2015). Finance and growth for microenterprises: evidence from rural China. World Development, 67, 38-56. https://doi.org/10.1016/j.worlddev.2014.10.008

Carree, M., van Stel, A., Thurik, R., \& Wennekers, S. (2002). Economic Development and Business Ownership: An Analysis Using Data of 23 OECD Countries in the Period 1976-1996. Small Business Economics, 19(3), 271-290. https://doi.org/10.1023/a:1019604426387

Chakravarty, S., \& Xiang, M. (2009). What discourages small businesses from asking for loans? The international evidence on borrower discouragement. SSRN Electronic Journal (February 2009). https://doi.org/10.2139/ssrn.1344098

Demetriades, P.O., and Rousseau, P.L. (2016) The changing face of financial development. Economics Letters 141, 87-90. https://doi.org/10.1016/j.econlet.2016.02.009

Demirgüç-Kunt, A., \& Maksimovic, V. (1998). Law, Finance, and Firm Growth. The Journal of Finance, 53(6), 2107-2137. https://doi.org/10.1111/0022-1082.00084

Demirgüç-Kunt, A., Čihák, M., Feyen, E., Beck, T., \& Levine, R. (2016). Financial Development and Structure Dataset. World Bank

Dias Duarte, F., Matias Gama, A. P., \& Paulo Esperança, J. (2017). Collateral-based in SME lending: The role of business collateral and personal collateral in less-developed countries. Research in International Business and Finance, 39, 406-422. https://doi.org/10.1016/j.ribaf.2016.07.005

Dinh, H. T., Mavridis, D. A., \& Nguyen, H. B. (2012). The binding constraint on the growth of firms in developing countries. In H. T. Dinh \& G. R. G. Clarke (Eds.), Performance of manufacturing firms in Africa: An empirical analysis (pp. 87-137). Washington, DC: The World Bank.

Dong, Y., \& Men, C. (2014). SME financing in emerging markets: Firm characteristics, banking structure and institutions. Emerging Markets Finance and Trade, 50(1), 120-149.

European Bank for Reconstruction and Development and World Bank. (2014). Business Environment and Enterprise Performance Survey (BEEPS). http://ebrdbeeps.com/data/2012$\underline{2013 /}$ 
European Investment Bank. (2012). Banking in the Eastern Neighbours and Central Asia Challenges and Opportunities. https://www.eib.org/attachments/efs/economic report banking enca en.pdf

Fernández, E., Iglesias-Antelo, S., López-López, V., Rodríguez-Rey, M., \& Fernandez-Jardon, C. M. (2019). Firm and industry effects on small, medium-sized and large firms' performance. BRQ Business Research Quarterly, 22(1), 25-35. https://doi.org/10.1016\%2Fi.brq.2018.06.005 Fowowe, B. (2017). Access to finance and firm performance: Evidence from African countries. Review of Development Finance, 7(1), 6-17. https://doi.org/10.1016/i.rdf.2017.01.006

Ghassibe, M., Appendino, M., \& Mahmoudi, S. E. (2019). SME financial inclusion for sustained growth in the Middle East and Central Asia. International Monetary Fund.

Girma, S., \& Vencappa, D. (2015). Financing sources and firm level productivity growth: evidence from Indian manufacturing. Journal of Productivity Analysis, 44(3), 283-292. https://doi.org/10.1007/s11123-014-0418-7

Gogokhia, T., \& Berulava, G. (2020). Business environment reforms, innovation and firm productivity in transition economies. Eurasian Business Review, 1-25.

https://doi.org/10.1007/s40821-020-00167-5

Gregory, B. T., Rutherford, M. W., Oswald, S., \& Gardiner, L. (2005). An Empirical Investigation of the Growth Cycle Theory of Small Firm Financing. Journal of Small Business Management, 43(4), 382-392. https://doi.org/10.1111/i.1540-627X.2005.00143.x

Hartarska, V., \& Nadolnyak, D. (2008). An Impact Analysis of Microfinance in Bosnia and Herzegovina. World Development, 36(12), 2605-2619. https://doi.org/10.1016/i.worlddev.2008.01.015

Hashi, I., \& Krasniqi, B. A. (2011). Entrepreneurship and SME growth: evidence from advanced and laggard transition economies. International Journal of Entrepreneurial Behavior \& Research, 17(5), 456-487. https://doi.org/10.1108/13552551111158817

Hashi, I., \& Toçi, V. Z. (2010). Financing Constraints, Credit, Rationing, and Financing Obstacles: Evidence from Firm Level Data in South Eastern Europe. In R. Matousek (Ed.), Money, Banking and Financial Markets in Central and Eastern Europe: 20 Years of Transition (pp. 62-97). London: Palgrave Macmillan UK.

Holzhacker, H. (2018). Uzbekistan Diagnostic: Assessing Progress and Challenges in Unlocking the Private Sector's Potential and Developing a Sustainable Market Economy. Official Use. Department of Economics, Policy and Governance (EPG) at the EBRD.

IMF (2013). Financial Access Survey. http://data.imf.org/?sk=e5dcab7e-a5ca-4892-a6ea598b5463a34c\&sld=1412015057755

IMF (2016). Financial System Stability Assessment. The Republic of Tajikistan. https://www.imf.org/external/pubs/ft/scr/2016/cr1641.pdf

International Group of Rating Agencies. (2018). Uzbekistan Credit Rating - Sovereign. https://raexpert.eu/reports/Press release Uzbekistan 08.03.2019.pdf

Kaminski, B., \& Raballand, G. (2009). Entrepôt for Chinese Consumer Goods in Central Asia: the puzzle of re-exports through Kyrgyz Bazaars. Eurasian Geography and Economics, 50(5), 581-590. https://doi.org/10.2747/1539-7216.50.5.581

Kaufmann, D., Kraay, A., \& Mastruzzi, M. (2016). The world development indicators. www.govindicators.org 
Khaleque, A. (2018). Performance of women entrepreneurs: Does access to finance really matter?.Eurasian Journal of Business and Economics, 11(21), 23-48. https://doi.org/10.17015/ejbe.2018.021.02

Kira, A. R. (2013). Determinants of financing constraints in East African countries' SMEs. International Journal of Business and Management, 8(8), 49-68. https://doi.org/10.5539/ijbm.v8n8p49

Krešić, A., Milatović, J., \& Sanfey, P. (2017). Firm Performance and Obstacles to doing business in Western Balkan. EBRD Working Paper, No 200.

Kumar, S., \& Rao, P. (2015). A conceptual framework for identifying financing preferences of SMEs. Small Enterprise Research, 22(1), 99-112. https://doi.org/10.1080/13215906.2015.1036504

Leitner, S. M. (2016). Financing Constraints and Firm Growth in Emerging Europe. The South East European Journal of Economics and Business, 11(1), 18-40. https://doi.org/10.1515/ieb2016-0002

Léon, F. (2020). The provision of long-term credit and firm growth in developing countries. Economic Modelling, 90, 66-78. https://doi.org/10.1016/i.econmod.2020.04.023

Makhmadshoev, D., Ibeh, K., \& Crone, M. (2015). Institutional influences on SME exporters under divergent transition paths: Comparative insights from Tajikistan and Kyrgyzstan. International Business Review, 24(6), 1025-1038. https://doi.org/10.1016/j.ibusrev.2015.02.010

Mateev, M., \& Anastasov, Y. (2010). Determinants of small and medium sized fast growing enterprises in central and eastern Europe: a panel data analysis. Financial Theory and Practice, 34(3), 269-295.

Mateev, M., Poutziouris, P., \& Ivanov, K. (2013). On the determinants of SME capital structure in Central and Eastern Europe: A dynamic panel analysis. Research in International Business and Finance, 27(1), 28-51. https://doi.org/10.1016/j.ribaf.2012.05.002

Mogilevskii, R. (2012). Re-export activities in Kyrgyzstan: Issues and prospects. UCA Working Papers. No 9, 2012.

Mohamad, M. R., Sidek, S., Ghee, W. Y., Abdullah, A. R., Ismail, N. A., \& Mustapha, N. (2015). Financial access for starting a business: Evidence of internal and external financial sources, and performance of Malaysian SMEs. Journal of Entrepreneurship and Business, 3(1), 1-16. https://doi.org/10.17687/jeb.0301.01

Morgan, P. J., Zhang, Y., \& Kydyrbayev, D. (2018). Overview of financial inclusion, regulation, financial literacy, and education in Central Asia and South Caucasus (No. 878). ADBI Working Paper Series.

Musta, E. (2017a). Analyses of financing needs of SMEs by size and age in Albania. European Journal of Economics, 1(1), 30-38.

Musta, E. (2017b). Patterns of Constraints in Access to Finance for SMEs in the Western Balkans Region. Academic Journal of Interdisciplinary Studies, 5(3 S1), 209. https://doi.org/10.5901/ajis.2016.v5n3s1p209

Nizaeva, M., \& Coşkun, A. (2018). Determinants of the Financing Obstacles Faced by SMEs: An Empirical Study of Emerging Economies. Journal of Economic and Social Studies, 7(2), 81-99. https://doi.org/10.14706/JECOSS17725 
Nizaeva, M., \& Coskun, A. (2019). Investigating the Relationship Between Financial Constraint and Growth of SMEs in South Eastern Europe. SAGE Open, 9(3), 2158244019876269. https://doi.org/10.1177\%2F2158244019876269

Raballand, G., \& Andrésy, A. (2007). Why should trade between Central Asia and China continue to expand?. Asia Europe Journal, 5(2), 235-252.

Rahaman, M. M. (2011). Access to financing and firm growth. Journal of Banking \& Finance, 35, 709-723.

Regasa, D., Fielding, D., \& Roberts, H. (2019). Sources of Financing and Firm Growth: Evidence from Ethiopia. Journal of African Economies 29(1), 26-45. https://doi.org/10.1093/jae/ejz012

Ruziev, K., \& Midmore, P. (2015). Connectedness and SME Financing in Post-Communist Economies: Evidence from Uzbekistan. The Journal of Development Studies, 51(5), 586-602. https://doi.org/10.1080/00220388.2014.989991

Saeed, A. (2009). Does nature of financial institutions matter to firm growth in transition economies?. Eurasian Journal of Business and Economics, 2(3), 73-90.

Sun, J., Maksimov, V., Wang, S. L., \& Luo, Y. (2021). Developing compositional capability in emerging-market SMEs. Journal of World Business, 56(3), 101148.

https://doi.org/10.1016/i.jwb.2020.101148

Suvankulov, F., \& Guc, Y. (2012). Who is trading well in Central Asia? A gravity analysis of exports from the regional powers to the region. Eurasian Journal of Business and Economics, 5(9), 21-43.

Ullah, B. (2020). Financial constraints, corruption, and SME growth in transition economies. The Quarterly Review of Economics and Finance, 75, 120-132. https://doi.org/10.1016/i.qref.2019.05.009

Wang, Y. (2016). What are the biggest obstacles to growth of SMEs in developing countries? An empirical evidence from an enterprise survey. Borsa Istanbul Review, 16(3), 167-176. https://doi.org/10.1016/j.bir.2016.06.001

Wooldridge, J. M. (2010). Econometric analysis of cross section and panel data. Cambridge, MA: MIT Press.

Wooldridge, J. M. (2012). Introductory econometrics: A modern approach. Scarborough, Ontario, Canada: Nelson Education.

World Bank. (2012). World Bank - Uzbekistan Partnership: Country Program Snapshot. http://siteresources.worldbank.org/INTUZBEKISTAN/Resources/294087-

$1285304341425 /$ Uzbekistan Snapshot.pdf

Xheneti, M., \& Bartlett, W. (2012). Institutional constraints and SME growth in postcommunist Albania. Journal of Small Business and Enterprise Development, 19(4), 607-626. https://doi.org/10.1108/14626001211277424

Yaldız Hanedar, E., Broccardo, E., \& Bazzana, F. (2014). Collateral requirements of SMEs: The evidence from less-developed countries. Journal of Banking \& Finance, 38, 106-121. https://doi.org/10.1016/i.jbankfin.2013.09.019. 